\title{
Exploring the effect of land use on ecosystem services: The distributive issues
}

\author{
Luis Filipe Gomes Lopes ${ }^{\mathrm{a}, \mathrm{b}}$,* João Manuel R. dos Santos Bento ${ }^{\mathrm{a}}$, \\ Artur F. Arede Correia Cristovão ${ }^{b}$, Fernando Oliveira Baptista ${ }^{c}$ \\ a Department of Forest Sciences and Landscape Architecture, University of Tras-os-Montes and Alto Douro (UTAD), PO Box 1013, 5001-901 Vila Real, \\ Portugal \\ ${ }^{\mathrm{b}}$ Centre for Transdisciplinary Development, University of Tras-os-Montes and Alto Douro (UTAD), PO Box 1013, 5001-901 Vila Real, Portugal \\ ${ }^{\mathrm{c}}$ Department of Rural Economics and Sociology, Instituto Superior de Agronomia, Tapada da Ajuda, 1349-017 Lisboa, Portugal
}

\section{A R T I C L E I N F O}

\section{Article history:}

Received 18 February 2014

Received in revised form

20 November 2014

Accepted 29 December 2014

\section{Keywords:}

Ecosystem services

Just distribution

Lorenz curve

Land use

Gini coefficient

\begin{abstract}
A B S T R A C T
The current debate of ecosystem services has focused more on monetary valuation methods and payments for environmental services (PES) then on the classic economic analysis (i.e. assumptions regarding: sustainability, justice and efficiency). This paper examines, taking into consideration ecosystem services, income distribution from different land uses to stakeholders. We study the Portuguese common land ecosystem, which is characterized as having a wide range of ecosystem services. Allowing that all the benefits can be translated into economic value, we estimated the total economic value (TEV) associated with these territories on 5 different land use situations: forest, shrubland, water bodies, mountain agriculture and other uses, and analyzed the current institutional arrangements around these territories. We found that the distribution of the benefits of different land uses is relatively inequality. The results showed that the contemporary institutional arrangements of wealth distribution ensure a relatively fair distribution insider of system; however this institutional arrangement is unable to ensure equitable distribution of wealth by external stakeholders. We can conclude that different types of land use provide a very asymmetric distribution of income by different groups of humans: land owners; citizens of a country, and residents of Earth.
\end{abstract}

Published by Elsevier Ltd.

\section{Introduction}

Distribution refers to the division on the flow of resources, as embodied in final goods and services between people's alternatives. A good distribution is fair or that is "reasonable", or at least the one who allowed the degree of inequality is limited within an acceptable range (Daly, 1992). There is a long history in economics of a consequentialist approach to distributive justice. From the classical economics' point of view, distributive justice is determined by whatever generates the best outcome for society (Mill, 1848). While in wealth production, humanity is restricted by natural laws, its distribution, is a matter of human institution solely. The distribution of wealth, therefore, depends on the laws and customs of society. The rules, by which it is determined, reflect the opinions and feelings of the ruling portion of the community (Mill, 1848). On this

\footnotetext{
* Corresponding author: Tel.: +351 259350883; fax: +351 259350859

E-mail address: lflopes@utad.pt (L.F.G. Lopes).
}

concern private property, institution is supposed to guarantee the fruits of the individuals' own labor and abstinence.

The main tool for analyzing economic inequality is the Lorenz curve (see Fig. 3), this concept was introduced by Lorenz (1905) who investigated the problem of measuring wealth concentration. This curve is an intuitive method for representing income distribution. Created by plotting cumulative income shares against cumulative population shares, the Lorenz curve forms the backbone of several inequality measures, including the popular Gini coefficient. The Lorenz curve has played a basic role, for example, in the analysis of income and earnings inequality (Sen, 1973; Slottje, 1989; Doiron and Barrett, 1996). The Gini coefficient (Gini, 1912), a measure of distribution inequality, is defined, geometrically, as the ratio of the area between the line of equal distribution and the observed Lorenz Curve to the area under the uniform distribution:

Gini $=\frac{A}{(A+B)}$

where $A$ is the area between the line of perfect equality and the Lorenz curve, and the area under the Lorenz curve is $B$. 
There are ways of decomposing the Gini coefficient but the component terms of total inequality are not always intuitively or mathematically appealing (Litchfield, 1999). The classical, mathematical, definition of Gini coefficient appears in the notation of the theory of relative mean difference:

Gini $=\frac{1}{2 n^{2} \bar{y}} \sum_{i=1}^{n} \sum_{j=1}^{n}\left[y_{i}-y_{j}\right]$

where $n$ is the number of individuals in the sample, $y_{i}$ is the income of individual $i, i \in(1,2, \ldots, n)$, and $\bar{y}=(1 / n) \Sigma y i$, the arithmetic mean income.

This coefficient has values within the range 0 (perfectly uniform distribution) to 1 (complete inequality).

Economists frequently take property rights approach to distributive justice, arguing that whatever distribution emerges from voluntary transactions (e.g. market transactions) is just (Farley, 2012). For ecosystem services there are two ways to put this approach into practice: the monetary valuation of ecosystem services based on estimates of willingness to pay (e.g. through contingent valuation, hedonic pricing, travel cost, etc.) and/or the use of market based instruments for allocation decisions concerning ecosystem services. In contemporary times Martinez-Alier and O'Connor (1999) discussed how valuations of today's externalities and also valuations of future externalities (and of environmental resources and services) will depend on the distribution, not only of property rights, but also of income and of power in socialinstitutional terms. In the case of ecosystems services, justice concerns entitlements to both the structural building blocks of ecosystems and the services they generate. The two of course are frequently in conflict (Farley, 2012).

\section{Ecosystem services: concept, valuation and distribution issues}

Ecosystem services (ES) research has become an important area of environmental science investigation over the last decades. The Millennium Ecosystem Assessment (MEA, 2005) and The Economic of Ecosystem and Biodiversity report (TEEB, 2010) represent two important milestones, aiming at mainstreaming ES in decisionmaking. Despite this, the use of ES is still limited both in plan and program-making (Geneletti, 2011) and environmental performance assessment of policy tools (Rega and Spaziante, 2013). In addition, the concept of ecosystem services does not, to our days, gather consensus amongst ecologists and economists (Boyd and Banzhaf, 2007; Wallace, 2007; Fisher and Turner, 2008) since linked ecological-economic systems are complex. In both fields, economics and ecology, which are often seen to have conflicting goals, ecosystem services are an extension of both economic externalities and ecological functioning, providing a nexus between the two fields (Fisher et al., 2009). Two commonly cited ES definitions are the one by Costanza et al. (1997) in that ecosystem services represent "the goods and services derived from the functions and utilized by humanity" and The Millennium Ecosystem Assessment (MEA, 2005) definition, in which ES are defined as "the benefits people obtain from ecosystems". Boyd and Banzhaf (2007) offer an alternative definition, i.e., ecosystem services are not the benefits humans obtain from ecosystems, but rather the ecological components directly consumed or enjoyed to produce human well-being. Fisher et al. (2009) define ecosystem services as the aspects of ecosystems utilized (actively or passively) to produce human wellbeing. Regardless of the author, ecosystem services are a function of complex interactions among species and their abiotic environment; complex use and utilization patterns; and various perceptions by beneficiaries (Fisher et al., 2009). From this meaning, any step in the system can be considered an ecosystem service regardless of where it occurs along the chain of events as long as humans use it to produce welfare.

There is an on-going debate on how to assign value to ecosystems services. The monetization (monetary valuation) of ecosystem services has been advocated by many as an optimal strategy to make nature visible to decision makers and financial markets, with the hope that this would eventually lead to the sustainable use of natural resources and their preservation. For other authors (see, among others, de Groot, 1992; Hanley, 1992; Diamond and Hausman, 1994; Vatn and Bromley, 1994), it is advisable to look at alternatives to ES for integration of nature into economic decisions (Baveye et al., 2013). The total economic value (TEV) is a concept made popular by Pearce and Turner (1990), and represents the several ways by which a natural resource, such as a forest, is valuable to people. Therefore TEV of a natural resource is the sum of its direct, indirect, option, and existence values (Pearce, 1991; Groombridge, 1992). TEV can be decomposed in to economic value for use in connection with utility value, economic value of non-use, related to the intrinsic value, where all issues of intrinsic value (ethical, religious and cultural) of natural resources are discussed. In the "total value of nature" Costanza et al. (1997) published the results of a comprehensive study estimating the value of annual global ecosystem services.

Ecosystem services are supplied to the economic system at a range of spatial and temporal scales. Hein et al. (2006) argued that ecosystem services can be generated at a range of ecological scales, and can be supplied to stakeholders at a different range of institutional scales. In light of distribution issues, one possibly important classification scheme considers the decision context of how ecosystem services relate to equity in the provision of human welfare (Fisher et al., 2009). This is important as it is now well accepted that failing environmental quality disproportionately affects people that are marginalized by the market economy (Dasgupta, 2002). This can be complex by the fact that stakeholders at different spatial scales have different interests in ecosystem services (Hein et al., 2006). The scale at which benefits and costs are captured is also a very important issue in terms of practicality and equity.

In this paper we will discuss the distributive issues associated with ecosystems services to different land uses. Today's understanding of the effects of land use on ecosystem services benefits distribution is far from complete. This paper is structured as follows: In the next section we will present details the methodological and data collection use in this case study: Portuguese common land ecosystem. Key findings emerging from the case study Section will analyze and discuss the result, followed by some brief conclusions.

\section{Research approach and methodology}

Case study methodology is well developed within social sciences. The process of designing a case study must be carried out in a methodical manner if the results are to be accurate and meaningful (Stake, 1995). Although findings originating from case studies cannot be generalized to populations, by following a rigorous methodological framework that includes maintaining the 'chain of evidence' and protecting against validity problems, case study research can strongly contribute to knowledge about social phenomena (Yin, 2009).

\section{Data collection}

Information on the monetary value of ecosystem services were sourced, mainly, from the "Ecosystem Service Valuation Database" (ESVD) developed by Van der Ploeg and de Groot (2010). This database includes more than 300 valuation studies and 1350 valuation estimates worldwide for different ecosystems, ecosystem 
services, and locations. Another used sources, equally important, were the relevant studies with data on ecosystem service values (Costanza et al., 1997; Mendes, 2005; Croitoru, 2007; de Groot et al., 2012), data from Portuguese governmental agencies (AFN, 2010; DGRF, 2007) and former associated projects devoted to the characterization and deepening of Portuguese commons insight, such as Baptista (2010).

A participatory approach was used to understand the institutional arrangements of wealth distribution. In this way, several interviews were collected during the year 2010 with different stakeholders, involved in the management of common land in northern Portugal. We performed the semistructured interviews using a flexible interview guide focused on four issues: stakeholder's expectations regarding to common land, ecosystem services, source of its legitimacy and specific goods/services used. Interviews, as opposed to surveys, allow greater flexibility, providing opportunities for the respondent to change the course of the conversation and bring up new issues that were not previously conceived by the researcher, thereby contributing to theory building (Glaser and Strauss, 1967; Goulding, 1999). These meetings build an array of different analysis of what exactly the realities of perceived management of common land are. Different institutional members were invited to participate in these meetings: state representatives, and non-governmental organizations (NGO) of different associative structures (Baladi, Forestis and Mountain Research Center (CIMO). Other key source of information used in this study was the process of public discussion on the National Program for the Upgrading of Common Land (AFN, 2010). These public information sessions were held in a partnership model with key Portuguese forest organizations. Land use information was taken from the last national forest inventory (IFN5, 2010). For socio-economic characterization of the study area, the maximum we could obtain in terms of data collection was a territorial unit parish using the data from INE (2001).

\section{Key findings emerging from the case study}

The Portuguese common land ecosystem: our case study

In a previous study (Lopes et al., 2013) an attempt was made to outline the emergence, evolution and transition of the institutionalization of common land ownership in Portugal, from the mid-nineteenth century to present time. In this paper the authors focused on the contemporary democratic governance of Portuguese common land ecosystem. Exploring the potential forms and modes of governance is an important task. We suggest that a more detailed and analytically highly useful typology of governance functions can be distilled from the common features lists of successful governance solutions as presented, for example, by Ostrom (1990) and Agrawal (2002). Debates on property regimes offer the best starting point for the argument that all governance solutions can be understood as forms of ownership. For two decades after Hardin's (1968) analysis of the commons, the nationalization or privatization of natural resources seemed to be the only alternative for resource tenure. In the 1980s, scholars working on common property arrangements made counter-arguments to Hardin's analysis which, together with accumulating empirical evidence, recognized common property as a viable form of resource tenure (Runge, 1986; Wade, 1987; Wade, 1988; Bromley and Cernea, 1989; Ostrom, 1990; Lopes et al., 2013).

With detailed historical and contemporary evidence, studies on the commons have shown that resource users often create institutional arrangements and management regimes that help them to allocate benefits equitably, over long time periods, and with only limited efficiency losses (McKean, 1992; Ostrom, 1992; Agrawal, 1999).

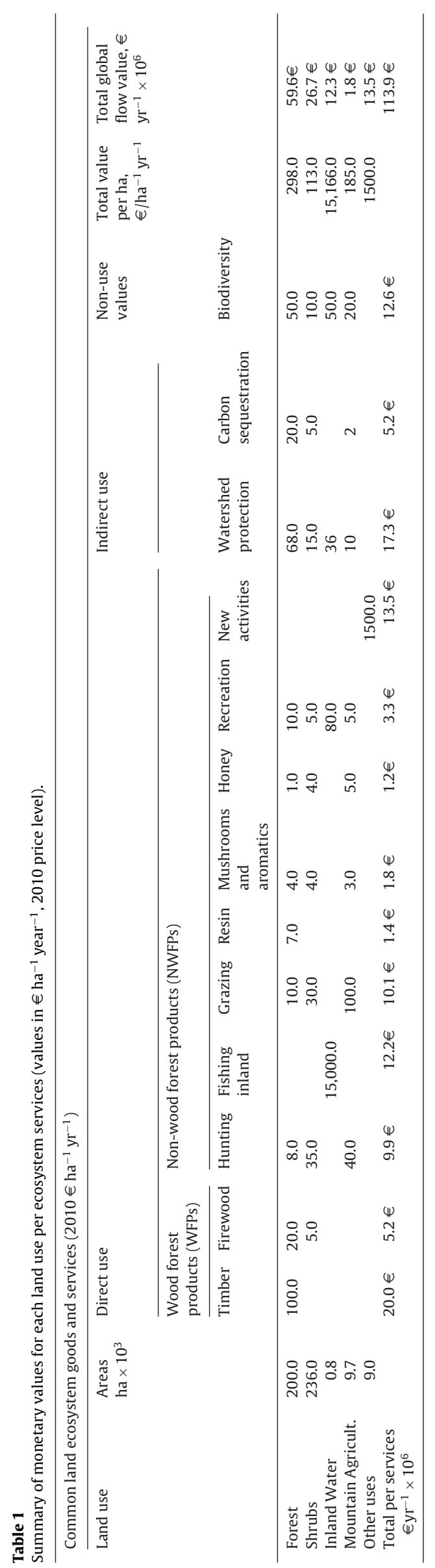




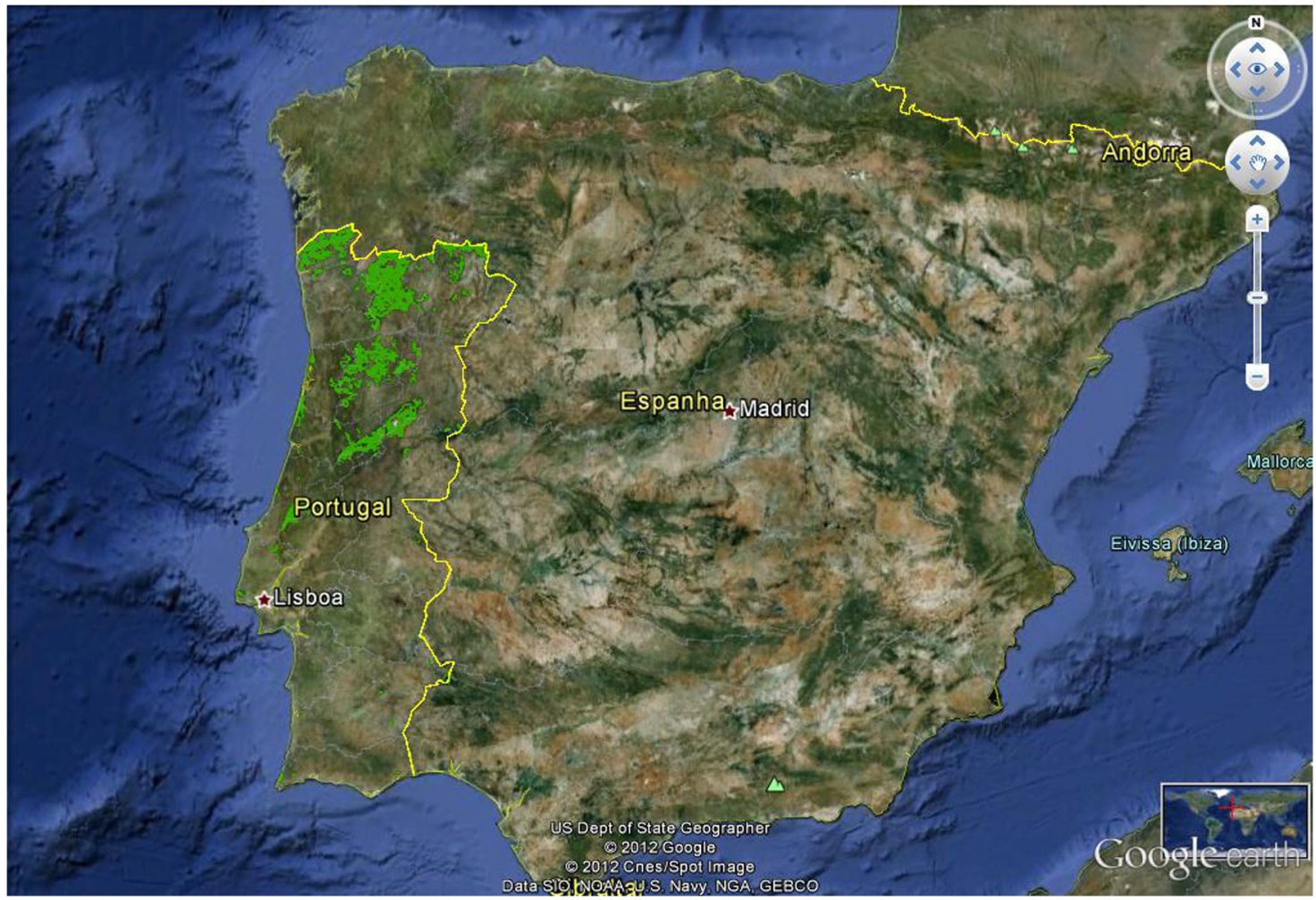

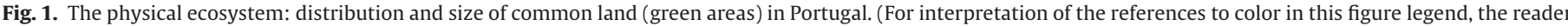
is referred to the web version of this article.)

Portuguese common land areas are located mostly in the mountains of northern and central Portugal (Fig. 1).

The common land ecosystem provides multiple goods and services (Pereira et al., 2005), including an exceptional richness in terms of biodiversity, which are crucial for the socio-economic development of rural areas. However, the social capital that is jointed in common land is old. Approximately $18,706 \mathrm{~km}^{2}$ of its area is occupied by parishes where there is a very low population density of 52.9 inhabitants per $\mathrm{km}^{2}$ (INE, 2001). Population density is often used as an indicator for classifying rural typologies. In Europe, local administrative units have been classified as rural if their population density is below 150 inhabitants per square kilometer (Van Eupen et al., 2012), whereas in Australia rural densities are reported in the order 0.9 persons per $\mathrm{Km}^{2}$ (Smailes et al., 2002). As an example, for the parish of Sistelo, one Portuguese mountain parish, Pereira et al. (2005) indicates a population density of 13 persons $/ \mathrm{km}^{2}$. In this way, using our study as a starting point and the guidelines proposed by WCPA (1998) and MEA (2005) we can characterize Portuguese common land ecosystem as having a high stock of natural resources (water, wildlife, temperate forests and other diverse landscapes) and a wide range of ecosystem services, and mainly located in rural regions with low population density.

Value of ecosystem services per "land use" in monetary units

For the purposes of this analysis, we used Fisher et al. (2009) general definitions of terminology. We use the term "ecosystem service" to refer to all the services provided by Portuguese common lands that directly or indirectly provide well-being (irrespective of whether they are intermediate or final products, processes or anthropogenic benefits). Total economic value (TEV) associated to all natural resources and ecosystem services, and annual flows of benefits provided by common lands under current management practices were estimated (Table 1 ). A similar approach has been used by Comino et al. (2014). In Appendix I detailed results are provided. We estimated the TEV associated to all ecosystem services of Portuguese common lands, and predicted the annual flows of benefits provided by common lands under current management practices, i.e., by different land use. We measured the average perhectare value of the current stock of different land uses, broken down by land use type and by component of total economic value.

Table 1 presets a summary of the monetary values for each land use per ecosystem services, (values in $€ \mathrm{ha}^{-1} \mathrm{yr}^{-1}, 2010$ price level). The Portuguese common land, as already mentioned, provides a wide range of benefits; however, most of them are barely recognized by society and have no commercial recognition. By relating the economic value of each output to the TEV for a representative hectare of common land in Portugal, we can perceive the scale exploitation of natural resources expressed in monetary units: Euros. The competition between land use: forest, shrubs, inland water, mount agriculture and other uses has been contentious. The results show the absolute and relative importance of the benefits associated with common land. In absolute terms we have a TEV of $€ 113.9$ million. Timber production is the service that presents the highest economic value, followed by watershed protection and what we designated as new activities: wind energy parks and quarrying. Several goods and ecosystem services produced in the common lands are intrinsically interdependent. Ecosystem service trade-offs arise from management choices made by humans, which can change the type, magnitude, and relative mix of services provided by ecosystems (Rodríguez et al., 2006; Chisholm, 2010).

\section{Distribution analysis}

A relevant issue for understanding the economic dynamics associated with the common land system is the distribution of benefits. We recall the distribution is only a matter of human institution. Gomes (2009) identified and analyzed the six main forms of 


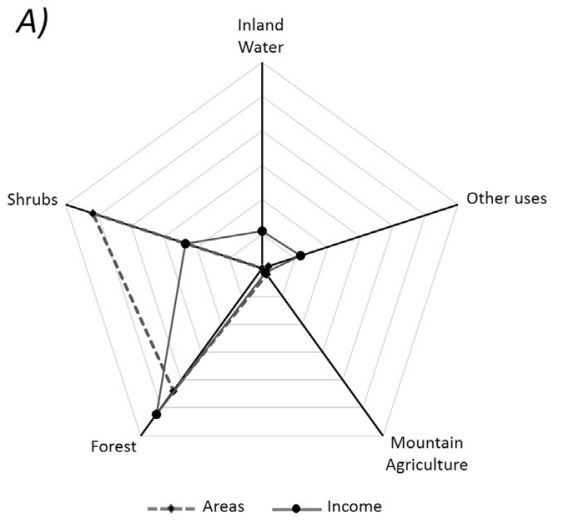

B)

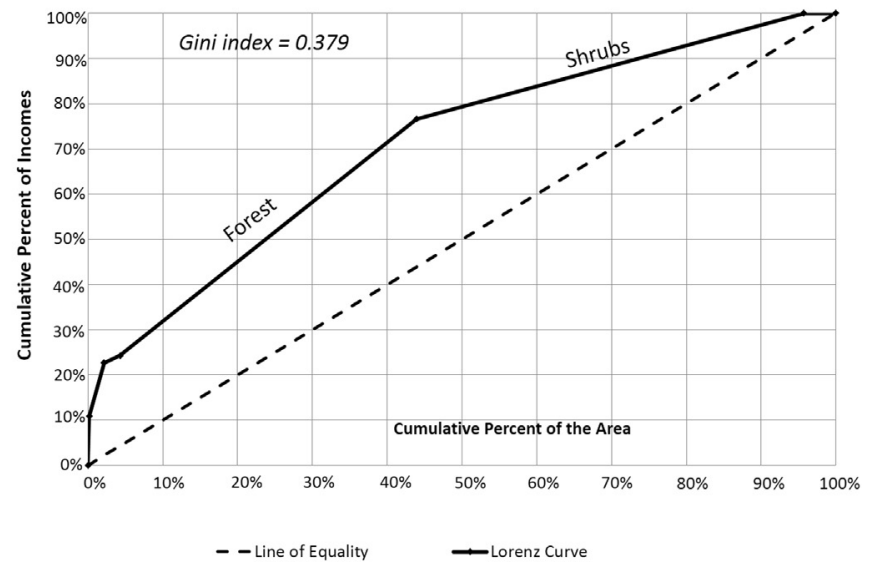

Fig. 2. (A) Land use extension (areas) and income; (B) adjusted Lorenz curves to different land use.

management of Portuguese common land, tracing the profile in terms of ability to generate benefits in a sustainable mode of appropriation of benefits by commoners and collective relevance of these benefits. This author found no significant differences among the six forms of management, in this way from this point on we will refer to only one form of Portuguese common land management.

\section{Effects of land use on benefits distribution}

It is widely known that changes in land use play a pivotal role in environmental and ecological changes, contribute to global change (Meyer and Turner, 1991; Lambin et al., 2001), and have important consequences for natural resources (Houghton et al., 1991; Houghton, 1994; Turner et al., 1990). Land use significantly affects key aspects of land system functioning. They are the primary source of altering ecosystem services, and affect the ability of biological systems to support human needs (Vitousek et al., 1997). However, understanding the effects of land use on distribution of benefits is far from complete. Ecosystem services and the natural capital stocks are critical to the functioning of the earth's life-supporting system. Dramatic land-use changes often have a significant negative impact on ecosystems and on goods and services (Kreuter et al., 2001).

Fig. 2A illustrates the extent of different land use and of its income. Land use is mainly occupied by shrubs that cover over $50 \%$ of the territory; nevertheless, its income represents only $23 \%$ of the total. Forests represent about $44 \%$ of total territory and have an income of $52 \%$. The other uses (Windfarms, inert operation of quarries and gravel pits) even with a diminished territorial expression provide an income that contributes $12 \%$ to the total. Mountain agriculture has a residual area and correspondent income.

We observe (Fig. 2B) that the distribution of the benefits of different land uses is relatively inequitable. This is due to the fact that some land uses (inland water, other uses) with lesser extent, produce higher wealth.

\section{Benefit distributions by people}

Understanding the magnitude and mix of net benefits received by particular groups is important to assess the degree of inequality. At the national level, there are, in Portugal, 10,356,117 registered residents, 3,650,757 families with an average of 2.8 individuals and $5,046,744$ dwellings (INE, 2001). Only $6 \%$ of this population, around 580,000 individuals, are commoners (Baptista, 2010). In Table 2 we illustrate the distribution of benefits in 3 groups: local users (commoners), rest of the country and citizens of the world. The group of local users (commoners) was subdivided into two groups: commoners without mountain farming (59\% of total commoners) and commoners with mountain farming ( $41 \%$ of total commoners). These percentages amongst the two groups were extrapolated from data presented by Baptista (2010).

We observe that commoners with mountain farming appear to retain more income. This is probably due to the existence of cattle herds that graze the common land. However the distribution of wealth is very fair within these commoners groups (see Table 2).

Among the three groups, there is a non-uniform distribution of benefits. Commoners can hold $45.3 \%$ of total benefits, leading to a
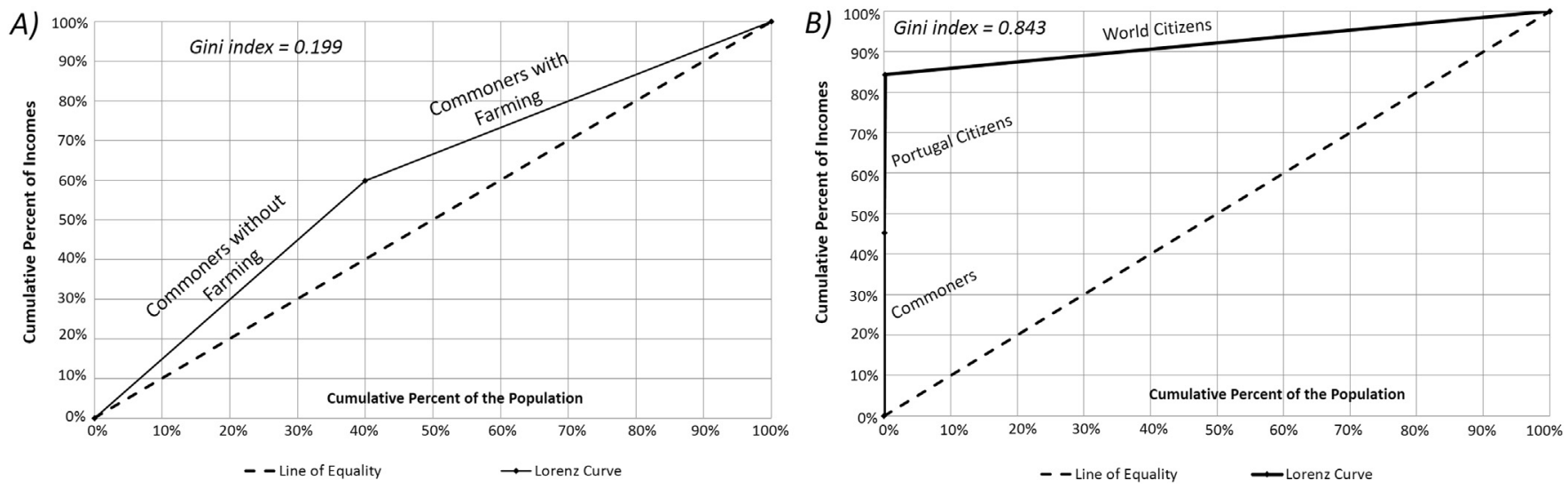

Fig. 3. Adjusted Lorenz curves: (A) inside of Portuguese land common; (B) outside of Portuguese land common. 


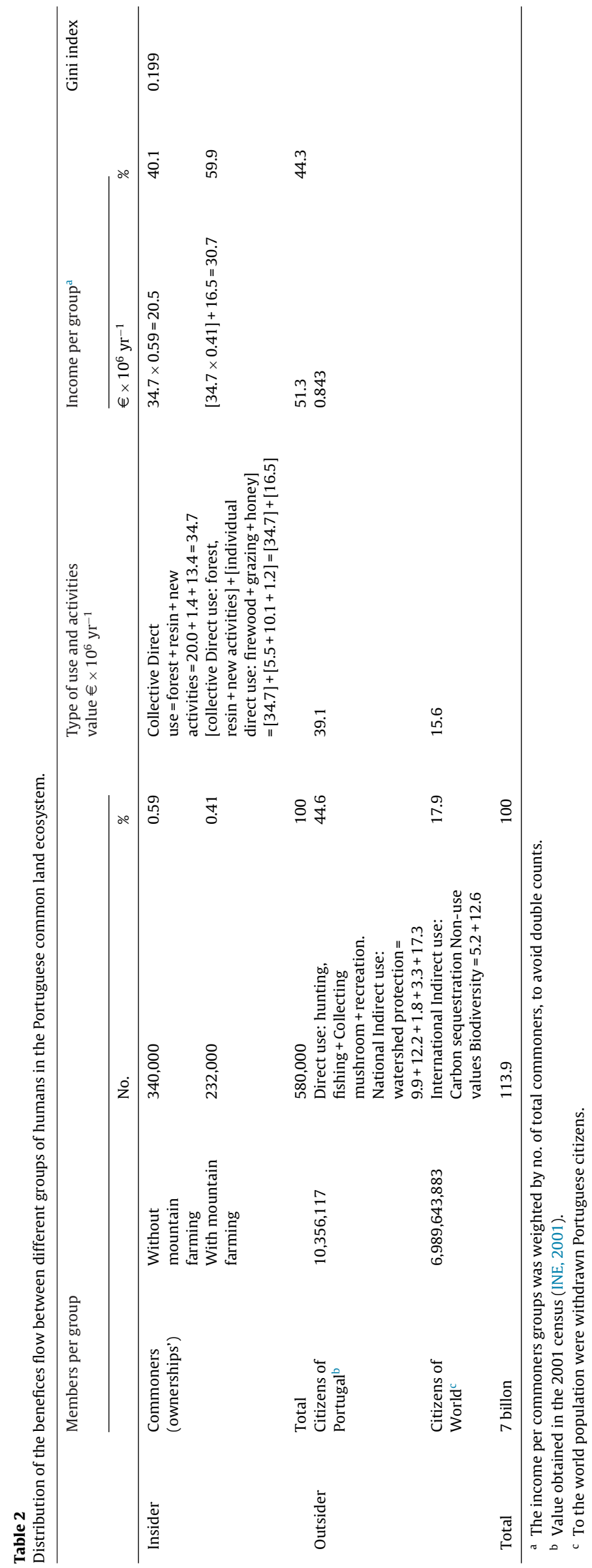

significant income for local communities. The Portuguese territory holds $39 \%$ of total benefits from common lands and the remaining $15.6 \%$ are distributed to the rest of the world.

By estimating and adjusting the Lorenz curve to data presented in Table 2 we observed (Fig. 3 ) that the distribution of the benefits to different people is relatively equitable inside of the system (Fig. 3A) but very inequitable to outside people (Fig. 3B).

Contemporary democratic governance of Portuguese common land has developed and used the organizational and institutional mechanisms, ensuring social equity distribution insider of it, with a Gini index of 0.199. On the contrary when we analyze the distribution with external stakeholders we find that the distribution is very asymmetric with a Gini index of 0.843 . Such measures appear to be sensitive or reflect inequalities across geographical areas or groups.

Concerning the democratic control vector, the commoners' assemblies have formally more democratic control than the Portuguese government. The management model is based on direct democracy, it is a political system where each commoner participate in decision-making in person, contrary to relying on intermediaries or representatives. However not all other stakeholders sit in the Commoners assemblies. This leads to opinions that look suspiciously at the distributive instances (such as the Commoners' Assemblies), seeing them as uncoordinated and/or opaque institutions often forgetting that the state, the rightful representative of the public interest, is a co-manager.

\section{Institutional arrangements to distribution of wealth}

In Table 3 we present the outcome of interviews, this Table contains all stakeholders that are directly or indirectly involved in the management of Portuguese common land and the source of its legitimacy. The existence of a large amount of public goods implies the involvement of a lot of stakeholders in the contemporary management of Portuguese common land. In a small, customary common property regime, resource users are often members of a community such as a village, which enforces and adjudicates the rules of resource use. The community performs all governmental functions, without separation of powers and, as such, the resource users can participate directly in the environmental decision-making affecting them. Resource users may themselves perform some governance functions such as monitoring of compliance with the rules of exclusion and authorized resource use.

The different stakeholder groups have heterogeneous interest, and often perceive very different costs and benefits from common land. We concluded that, in a democracy, new institutional economics contributes to emerging institutional ecological economics by shedding new light on urgent areas of environmental policy and governance. The institutional approach helps us to examine how the attributes of environmental resources and their users can create interdependence and conflicts.

A reasonable guideline for devolution programs (Lopes et al. 2013) is to ensure that user groups' rights are commensurate with their responsibilities in managing the resource. This implies that cases of "community-based resource management" (where users take over more of the management function) would have stronger user rights than cases of joint management (where the state retains an active role in managing the system). However, even in the case of joint or co-management, some official affirmation of the users rights may be required to coalesce or strengthen local collective action, and to place users on a relatively more even footing with the governmental agency staff. The intra-household and intra-community bargaining literature has shown that those with more assets (especially property rights) are treated better and are better able to negotiate than those without assets (Agarwal, 
Table 3

Stakeholders in democratic governance of Portuguese common land.

\begin{tabular}{|c|c|c|c|c|c|}
\hline \multicolumn{2}{|c|}{ Stakeholders } & \multirow{2}{*}{$\begin{array}{l}\text { Stakeholder expectations } \\
\text { regarding to common land }\end{array}$} & \multirow{2}{*}{$\begin{array}{l}\text { Source of its legitimacy } \\
\text { Law, rules-in-use }\end{array}$} & \multirow{2}{*}{$\begin{array}{l}\begin{array}{l}\text { Specific good and } \\
\text { services they use }\end{array} \\
\text { Firewood, grazing } \\
\text { water, honey }\end{array}$} & \multirow{2}{*}{$\begin{array}{l}\text { Characteristics } \\
\text { of goods }\end{array}$} \\
\hline Interns & Commoners & & & & \\
\hline & $\begin{array}{l}\text { Local management } \\
\text { organizations }\end{array}$ & Income and resources & Law, rules-in-use & $\begin{array}{l}\text { Income to sell: } \\
\text { - timber } \\
\text { - resin } \\
\text { windfarm }\end{array}$ & Non-rival \\
\hline & Parish & $\begin{array}{l}\text { Resources and revenues for the } \\
\text { benefit of the parish }\end{array}$ & Law, rules-in-use & $\begin{array}{l}\text { Income to sell: } \\
\text { - timber } \\
\text { - resin } \\
\text { windfarm }\end{array}$ & Non-rival \\
\hline \multirow[t]{5}{*}{ Externs } & National Forest Authority & $\begin{array}{l}\text { Areas producing national } \\
\text { wealth Minimize conflicts }\end{array}$ & Laws Public interest & Income to timber & Non-rival \\
\hline & $\begin{array}{l}\text { National Authority of } \\
\text { conservation of } \\
\text { biodiversity }\end{array}$ & $\begin{array}{l}\text { conservation of biodiversity } \\
\text { and ecosystem }\end{array}$ & Laws Public interest & $\begin{array}{l}\text { Biodiversity } \\
\text { Watershed protection }\end{array}$ & Non-rival \\
\hline & Environment ONG's & $\begin{array}{l}\text { A partner in the conservation } \\
\text { of biodiversity and ecosystem }\end{array}$ & $\begin{array}{l}\text { Specific interests } \\
\text { (environment) }\end{array}$ & $\begin{array}{l}\text { Biodiversity } \\
\text { Watershed protection }\end{array}$ & Non-rival \\
\hline & Hunting and fishing clubs & $\begin{array}{l}\text { Resources hunting and fish at } \\
\text { low cost }\end{array}$ & Specific interests & Game and fish & Rival \\
\hline & $\begin{array}{l}\text { Business and industrial } \\
\text { companies }\end{array}$ & $\begin{array}{l}\text { Strategic locations for } \\
\text { installation of infrastructure at } \\
\text { low cost }\end{array}$ & Specific interests & $\begin{array}{l}\text { Raw materials } \\
\text { Wind farms, inert } \\
\text { quarries }\end{array}$ & Rival \\
\hline
\end{tabular}

1997; Haddad et al., 1997; Quisumbing, 1994). Over than 80\% of Portuguese common land are co-management with the central government. Berkes (2002) noted that co-management is not merely a task of assigning components of an environmental problem to various groups of participants and their associated property regimes. Because of cross-scale social and biophysical linkages, the interplay between local and central governance structures must also be taken into account (Young, 2002; Hill et al., 2010). Additionally, co-management is not necessarily between a monolithic central government and one coherent community. Rather, it is a more complex arrangement between multiple sources of governance, or what has been referred to as polycentricity (McGinnis, 1999; Ostrom, 1990). This principle also applies to negotiations and interactions between the users and agencies in co-management situations: users with recognized rights are more likely to have a say in decision-making. With the Portuguese April 25th 1974 revolution there was a spread of common land ownership, primarily as a result of the presence of several institutions asking for exclusion powers; the persistence of the previous administrative authorities (Forest Service) is then tied with the incipient institutionalization of the new commoners' committees and the sustained wishes of small farmers.

\section{Conclusion}

There is an on-going debate on how to assign value to ecosystems services. There are several limitations in this study especially with regard to the precision of the monetary estimation of some ecosystem services. However, we believe that distribution and sustainability issues are the debate that follows. In this paper we have argued that there are interdependencies between land use and distributive issues on ecosystem services. We found that the different land use arrangements imply distinct problems in distribution of its benefits. We observed that, as we move away from naturalized (forest and shrubs) to manmade (mountain agriculture and other uses) land cover the distribution of benefits becomes more asymmetric. We can conclude that different types of land cover allow different types of activities and provide a very asymmetric distribution of income. The forest land use is the one with more products/services, therefore the economic value per ha compared with other land uses (inland water and other uses) is low. It is expected, and supported by empirical evidence, that commoners prefer these uses to traditional ones (forests and pastures). Deforestation is a reality in Portuguese common land, however, forest land use is the more balanced land use for wealth distribution.

The Lorenz curves are given for distribution discrepancies between different groups; it is now clear for us the need to measure inequality, taking into account ecosystem services. The groups of people are not homogeneous, and computation of inequality in the distribution of Portuguese wealth between Portuguese and non-Portuguese citizens is important since some of ecosystem services can have planetary scales (i.e. conservation of biodiversity and climate change). However we have a full awareness of the disparity in the total population between Portugal and the rest of the World. The neoclassic approach may tend to view these exercises as almost meaningless. The results showed that the contemporary institutional arrangements of wealth distribution ensure a relatively equitable distribution insider of system, however this institutional arrangement is unable to ensure equitable distribution of wealth by external stakeholders. No Portuguese government or non-governmental regulatory body is accountable to non-Portuguese people for management of Portuguese common lands. The relationship between Portuguese citizens and transnational groupings like the WTO or the EU is more complex, but certainly is not the same as the relationship of the Portuguese people to their own government.

Researchers that examine measures of horizontal inequalities have generally found stronger evidence for a positive relationship between inequality and conflict (Stewart, 2002; Østby, 2008; Østby et al., 2009; Cederman et al., 2011). We observed that there is a need for significant developments in institutional arrangements, in order to make them more just on wealth distribution to external stakeholders. The per capita value to non-Portuguese citizens of all the goods that are produced by Portuguese common lands is bound to be very small, because of the disparity in total population between Portugal and the rest of the world. This argument is valid on the demand and supply point of view, thus the value of ecosystem services seems to have been greatly underestimated. The straightjacket of neoclassical theory will have to be broken in other to open the path to alternative ways of integrating nature and economics. 


\section{Appendix A. Supplementary data}

Supplementary data associated with this article can be found, in the online version, at http://dx.doi.org/10.1016/j.landusepol. 2014.12.008.

\section{References}

AFN, 2010. Programa Nacional para a Valorização dos Territórios Comunitários (PNVTC). Autoridade Florestal Nacional, Lisboa.

Agarwal, B., 1997. Environmental action, gender equity and women's participation. Dev. Change $28(1), 1-44$.

Agrawal, A., 1999. Greener Pastures: Politics, Markets, and Community Among a Migrant Pastoral People. Duke University Press, Durham, NC.

Agrawal, A., 2002. Common resources and institutional sustainability. In: Ostrom, E., Dietz, T., Dolšak, N., Stern, P.C., Stonich, S., Weber, E.U. (Eds.), The Drama of the Commons. National Academy Press, Washington, DC.

Baptista, F.O., 2010. O Espaço Rural. Declínio da agricultura. Celta Editora, Lisboa.

Baveye, P.C., Baveye, J., Gowdy, J., 2013. Monetary valuation of ecosystem services: it matters to get the timeline right. Ecol. Econ. 95, 231-235.

Berkes, F., 2002. Cross-scale institutional linkages: perspectives from the bottom up. In: Ostrom, E., Dietz, T., Dolsak, N., Stern, P.C., Stonich, S., Weber, E.U. (Eds.), The Drama of the Commons. National Academies Press, Washington, DC, USA, pp. 293-322.

Boyd, J., Banzhaf, S., 2007. What are ecosystem services? The need for standardized environmental accounting units. Ecol. Econ. 63, 616-626.

Bromley, D.W., Cernea, M.M., 1989. The Management of Common Property Natural Resources: Some Conceptual and Operational Fallacies. World Bank Discussion Paper 57, Washington, DC.

Cederman, L.E., Weidmann, N.B., Gleditsch, K.S., 2011. Horizontal inequalities and ethno-nationalist civil war: a global comparison. Am. Polit. Sci. Rev. 105 (3), 478-495.

Chisholm, R.A., 2010. Trade-offs between ecosystem services: water and carbon in a biodiversity hotspot. Ecol. Econ. 69:, 1973-1987.

Comino, E., Bottero, M., Pomarico, S., Rosso, M., 2014. Exploring the environmental value of ecosystem services for a river basin through a spatial multicriteria analysis. Land Use Plann. 36, 381-395.

Costanza, R., d'Arge, R., de Groot, R., Farber, S., Grasso, M., Hannon, B., Limburg, K., Naeem, S., O’Neill, R.V., Paruelo, J., Raskin, R.G., Sutton, P., van den Belt, M., 1997. The value of the world's ecosystem services and natural capital. Nature 387, 253-260.

Croitoru, L., 2007. Valuing the non-timber forest products in the Mediterranean region. Ecol. Econ. 63 (4), 768-775.

Daly, H.E., 1992. Allocation, distribution, and scale: toward an economics that is efficient, just, and sustainable. Ecol. Econ. 6, 185-193.

Dasgupta, P., 2002. Economic development, environmental degradation, and the persistence of deprivation in poor countries. World Summit on Sustainable Development, Johannesburg.

De Groot, R., Brander, L., van der Ploeg, S., Costanza, R., Bernard, F., Braat, L., et al., 2012. Global estimates of the value of ecosystems and their services in monetary units. Ecosyst. Serv. 1, 50-61.

de Groot, R.S., 1992. Functions of Nature. Wolters-Noordhoff, Amsterdam, The Netherlands.

DGRF, 2007. National Forest Strategy. Direcção geral dos Recursos Florestais, Lisbon.

Diamond, P.A., Hausman, J.A., 1994. Contingent valuation: is some number better than no number? J. Econ. Perspect. 8 (4), 45-64.

Doiron, D.J., Barrett, G.F., 1996. Inequality in male and female earnings: the role of hours and earnings. Rev. Econom. Statist. 78, 410-420.

Farley, J., 2012. Ecosystem services: the economics debate. Ecosyst. Serv. 1 (1), 40-49.

Fisher, B., Turner, R.K., 2008. Ecosystem services: classification for valuation. Biol. Conserv. 141, 1167-1169.

Fisher, B., Turner, R.K., Morling, P., 2009. Defining and classifying ecosystem services for decision making. Ecol. Econ. 68, 643-653.

Geneletti, D., 2011. Reasons and options for integrating ecosystem services in strategic environmental assessment of spatial planning. Int. J. Biodivers. Sci. Ecosyst. Serv. Man. 7, 143-149.

Gini, C., 1912. Memorie di metodologia statistica. Variabilità e Concentrazione 1.

Glaser, A., Strauss, L., 1967. The Discovery of Grounded Theory; Strategies for Qualitative Research. Aldine Pub. Co, Chicago.

Gomes, P.F.S.C., 2009. Posse, gestão e uso de recursos em regime de propriedade comum-os baldios do Norte de Portugal. Tese de doutoramento em Engenharia Agronómica. Instituto Superior de Agronomia da Universidade Técnica de Lisboa.

Goulding, C., 1999. In: Gilbert, K. (Ed.), Grounded Theory: Some Reflections on Paradigm, Procedures and Misconceptions, Working Paper Series. University of Wolverhampton, Wolverhampton Business School, Shropshire, UK, p. 26.

Groombridge, B., 1992. Global Diversity: Status of the Earth's Living Resources. Chapman and Hall, London.

Haddad, L., Hoddinott, J., Alderman, H., February. 1997. Intrahousehold Resource Allocation: An Overview, Policy Research Working Paper 1255. The World Bank, Washington, DC

Hanley, N., 1992. Are there environmental limits to cost-benefit analysis? Environ. Resour. Econ. 2, 33-59.

Hardin, G., 1968. Tragedy of commons. Science 162, 1243-1248.
Hein, L., van Koppen, K., de Groot, R.S., van Lerland, E.C., 2006. Spatial scales, stakeholders and the valuation of ecosystem services. Ecol. Econ. 57 (2), 209-228.

Hill, R., Williams, K.J., Pert, P.L., Robinson, C.J., Dale, A.P., Westcott, D.A., Grace, R.A., O'Malley, T., 2010. Adaptive community-based biodiversity conservation in Australia's tropical rainforests. Environ. Conserv. 37 (1), 73-82.

Houghton, R.A., 1994. The worldwide extent of land-use change. Bioscience 44 305-313.

Houghton, R.A., Lefkowitz, D.S., Skole, D.L., 1991. Changes in the landscape of LatinAmerica between 1880 and 1985 I. Progressive loss of forests. Forest Ecol Manage. 38, 143-172.

IFN5, 2010. Inventário Florestal Nacional, Portugal Contimental. IFN5 2005-2006 AFN, Lisboa.

INE., 2001. XIV Recenseamento geral da população. Instituto Nacional de Estatística INE, Lisbon, Portugal.

Kreuter, U.P., Harris, H.G., Matlock, M.D., Lacey, R.E., 2001. Change in ecosystem service values in the San Antonio area, Texas. Ecol. Econ. 39, 333-346.

Lambin, E.F., Turner, B.L., Geist, H.J., Agbola, S.B., Angelsen, A., Bruce, J.W., Coomes, O.T., Dirzo, R., Fischer, G., Folke, C., George, P.S., Homewood, K., Imbernon, J., Leemans, R., Li, X., Moran, E.F., Mortimore, M., Ramakrishnan, P.S., Richards, J.F., Skanes, H., Steffen, W., Stone, G.D., Svedin, U., Veldkamp, T.A., Vogel, C., Xu, J. 2001. The causes of land-use and land-cover change: moving beyond the myths. Global Environ. Change 11, 261-269.

Litchfield, J.A., 1999. Inequality: Methods and Tools World Bank's Web Site on Inequality, Poverty, and Socio-economic Performance.

Lopes, L.F.G., Bento, J.M.R.S., Cristovão, A.F.C., Baptista, F.O., 2013. Institutionalization of common land property in Portugal: tragic trends between commons and anticommons. Land use Policy 35, 85-94.

Lorenz, M.C., 1905. Methods of measuring the concentration of wealth. J. Am. Statist. Assoc. 9, 209-219.

Martinez-Alier, J., O’Connor, M., 1999. Distribution issues: an overview. In: Van den Bergh, J. (Ed.), Handbook of Environmental and Resource Economics. Edward Elgar, Cheltenham.

McGinnis, M., 1999. Polycentricity and Local Public Economies: Readings from theWorkshop in Political Theory and Policy Analysis. University of Michigan Press Ann Arbor, MI, USA.

McKean, M., 1992. Success on the commons: a comparative examination of institutions for common property resource management. J. Theor. Polit. 4 (3), 247-281.

MEA., 2005. Millennium Ecosystem Assessment. Island Press, Washington, DC, USA

Mendes, A., 2005. Valuing Mediterranean Forests, Towards Total Economic Value. CABI Publishing, CAB International, Portugal/Wallingford, Oxfordshire, pp. $331-371$.

Meyer, W.B., Turner II, B.L., 1991. Changes in Land Use and Land Cover: A Global Perspective. Cambridge University Press, Cambridge.

Mill, J.S., 1848. Principles of Political Economy 2 vols. John W. Parker, London.

Østby, G., 2008. Polarization, horizontal inequalities and violent civil conflict. J. Peace Res. 45 (2), 143-162.

Østby, G., Ragnhild Norda, s, Rød, J.K., 2009. Regional Inequalities and civil conflict in Sub-Saharan Africa. Int. Stud. Quart. 53 (2), 301-324.

Ostrom, E., 1990. Governing the Commons: The Evolution of Institutions for Collective Action. Cambridge University Press, Cambridge.

Ostrom, E., 1992. The rudiments of a theory of origins, survival and performance of common-property institutions. In: Bromley, D.W., Feeny, D., McKean, M.A. Peters, P., Gilles, J.L., Oakerson, R.J., Runge, C., Thomson, J.T. (Eds.), Making the Commons Work: Theory, Practice and Policy. EE.U.U., Institute for Contemporary Studies Press, San Francisco, California.

Pearce, D., Turner, R.K., 1990. Economics of Natural Resources and the Environment. Harvester Wheatsheaf, New York

Pearce, D.W., 1991. An economic approach to saving the tropical forests. In: Helm, D. (Ed.), Economic Policy Towards the Environment. Blackwell, Oxford, pp. 239-262.

Pereira, E., Queiroz, C., Pereira, H., Vicente, L., 2005. Ecosystem services and human well-being: a participatory study in a mountain community in Portugal. Ecol. Soc. 10 (2), 14

Quisumbing, A., 1994. Improving Women's Agricultural Productivity as Farmers and Workers, ESP Discussion Paper Series No. 37. The World Bank, Washington, DC.

Rega, C., Spaziante, A., 2013. Linking ecosystem services to agri-environmental schemes through SEA: A case study from Northern Italy. Environ. Impact. Asses. 40, 47-53.

Rodríguez, J.P., Beard, T.D., Bennett Jr., E.M., Cumming, G.S., Cork, S., Agard, J., Dobson, A.P., Peterson, G.D., 2006. Trade-offs across space, time, and ecosystem services. Ecol. Soc. 11 (1), 28

Runge, C.F., 1986. Common property and collective action in economic development. World Dev. 14, 623-635.

Sen, A., 1973. On Economic Inequality. Norton, New York.

Slottje, D.J., 1989. The Structure of Earnings and the Measurement of Income Inequality in the US, North-Holland, Amsterdam.

Smailes, P.J., Argent, N., Griffin, T.L.C., 2002. Rural population density: its impact on social and demographic aspects of rural communities. J. Rural Stud. 18 (4) 385-404.

Stake, R.E., 1995. The Art of Case Study Research. Sage Publications, Thousand Oaks CA.

Stewart, F., 2002. Horizontal Inequalities: A Neglected Dimension of Development. Queen Elizabeth House Working Paper Series 81. University of Oxford.

TEEB, 2010. The Economics of Ecosystems and Biodiversity Report for Business Executive Summary. In: United Nations Environment Programmer and European Commission. 
Turner II, B.L., Clark, W.C., Kates, R.W., Richards, J.F., Mathews, J.T., Meyer, W. B (Eds.), 1990. The Earth as Transformed by Human Action: Global and Regional Changes in the Biosphere Over the Past 300 Years. Cambridge University Press, Cambridge.

Van der Ploeg, S., de Groot, R.S., 2010. The TEEB Valuation Database - a Searchable Database of 1310 Estimates of Monetary Values of Ecosystem Services. Foundation for Sustainable Development, Wageningen, the Netherlands.

Van Eupen, M., Metzger, M.J., Pérez-Soba, M., Verburg, P.H., van Doorn, A., Bunce, R.G.H., 2012. A rural typology for strategic European policies. Land Use Policy 29 (3), 473-482.

Vatn, A., Bromley, D., 1994. Choices without prices without apologies. J. Environ. Econ. Manage. 26, 129-148.

Vitousek, P.M., Mooney, H.A., Lubchenco, J., Melillo, J.M., 1997. Human domination of earth's ecosystems. Science 277, 494-499.
Wade, R., 1987. The management of common property resources: collective action as an alternative to privatisation or state regulation. Cambridge J. Econ.s 11 , 95-106.

Wade, R., 1988. Village Republics: Economic Conditions for Collective Action in South India. Cambridge University Press, Cambridge.

Wallace, K.J., 2007. Classification of ecosystem services: problems and solutions, Biol. Conserv. 139 (3-4), 235-246.

WCPA., 1998. World Commission on Protected Areas "Economic Values of Protected Areas - Guidelines for Protected Area Managers". IUCN - The World Conservation Union.

Yin, R.K., 2009. Case Study Research: Design and Methods, 4th ed. Sage Publications, Los Angeles, California.

Young, O., 2002. The Institutional Dimensions of Environmental Change: Fit, Interplay, and Scale. MIT Press, Cambridge, MA, USA. 